\title{
Actinomadura hallensis sp. nov., a novel actinomycete isolated from Mt. Halla in Korea
}

Correspondence Soon Dong Lee sdlee@cheju.ac.kr
As a result of phylogenetic and chemotaxonomic analyses, the description of the family Thermomonosporaceae was emended by Zhang et al. (2001) and the family currently contains four genera: Actinomadura, Actinocorallia, Spirillospora and Thermomonospora. Although the members of these genera are phylogenetically intermixed and share major phenotypic characteristics (Goodfellow, 1992; Kroppenstedt \& Goodfellow, 1991; Zhang et al., 1998, 2001), they differ in terms of morphology. They are phylogenetically distinct from the members of the other two families in the suborder Streptosporangineae, namely Streptosporangiaceae and Nocardiopsaceae (Zhang et al., 1998, 2001). In their extensive study, Zhang et al. (2001) proposed that four Actinomadura species, Actinomadura aurantiaca, Actinomadura glomerata, Actinomadura libanotica and Actinomadura longicatena, be transferred to the genus Actinocorallia, and that Excellospora viridilutea, the only species of the genus Excellospora, be reclassified as Actinomadura viridilutea.

The genus Actinomadura contains aerobic, Gram-positive, non-acid-fast, non-motile, chemo-organotrophic actinomycetes that produce well-developed, non-fragmenting vegetative mycelia and aerial hyphae that differentiate into surface-ornamented spore chains. These chains are of various lengths and can be straight, hooked or spiral. The genus currently comprises 31 species with validly published names, although the species status of some strains remains

The GenBank/EMBL/DDBJ accession number for the 16S rRNA gene sequence of strain $\mathrm{H} 647-1^{\top}$ is D0076484. uncertain, and further comparative studies are needed (Zhang et al., 2001). Members of the genus are characterized chemotaxonomically by type III/B cell walls (mesodiaminopimelic acid and madurose are present) with peptidoglycan structures of the acetyl type. The predominant menaquinone types are $\mathrm{MK}-9\left(\mathrm{H}_{4}\right), \mathrm{MK}-9\left(\mathrm{H}_{6}\right)$ and MK-9 $\left(\mathrm{H}_{8}\right)$. The phospholipid pattern is PI (diphosphatidylglycerol and phosphatidylinositol are present as major phospholipids) and the fatty acid pattern is type 3a (branched saturated and unsaturated fatty acids plus tuberculostearic acid) (Kroppenstedt et al., 1990; Kroppenstedt \& Goodfellow, 1991).

In this paper, we describe the characterization and classification of strain H647-1 ${ }^{\mathrm{T}}$, isolated in 1992 from a soil sample collected on Mt. Halla, Jeju Island, Republic of Korea.

Strain $\mathrm{H} 647-1^{\mathrm{T}}$ was isolated using starch/casein agar and was maintained on yeast extract/malt extract agar (ISP 2 medium) and as mycelial fragments or spores in $20 \%(\mathrm{v} / \mathrm{v})$ glycerol or as lyophilized cells. For comparative purposes, the following type strains of the genus Actinomadura were used in this study: Actinomadura livida DSM $43677^{\mathrm{T}}$ $\left(=\mathrm{IMSNU} 22191^{\mathrm{T}}\right)$ and Actinomadura yumaensis KCTC $9495^{\mathrm{T}}\left(=\mathrm{IMSNU} 22167^{\mathrm{T}}\right)$. To examine the degree of growth and pigmentation, strain $\mathrm{H} 647-1^{\mathrm{T}}$ was grown on ISP 2 medium, oatmeal agar (ISP 3 medium) and inorganic salts/starch agar (ISP 4 medium) as described by Shirling \& Gottlieb (1966). For scanning electron microscopy, the agar blocks containing the organism (cultivated on ISP 4 medium for 3 weeks at $28^{\circ} \mathrm{C}$ ) were fixed with the vapour of 


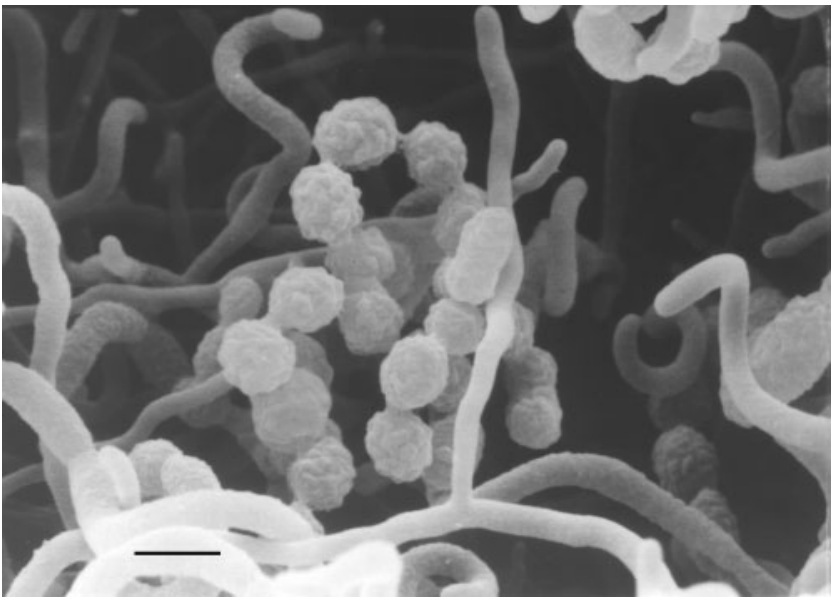

Fig. 1. Scanning electron micrograph of strain $\mathrm{H} 647-1^{\top}$ grown on ISP 4 medium for 3 weeks. Bar, $0.8 \mu \mathrm{m}$.

$1 \%$ osmium tetroxide. The specimen was dehydrated using a graded ethanol and isoamyl acetate series and then critical-point-dried. After being sputter-coated with gold, the specimen was observed under a scanning electron microscope (Cambridge Stereoscan 260). The cultural characteristics of strain $\mathrm{H} 647-1^{\mathrm{T}}$ were recorded after 3 weeks incubation at $28^{\circ} \mathrm{C}$. The isolate showed good growth on all of the media tested and produced well-developed and extensively branched substrate mycelia. The colours of the reverse sides of colonies were variable, according the media tested, e.g. blackish purple on ISP 2 medium, moderate brown on ISP 3 medium and greyish reddish purple on ISP 4 medium. A dark-brown-coloured, diffusible pigment was produced on ISP 2 medium. Moderately well-developed aerial mycelia were produced on ISP 3 and ISP 4 media, from which, at maturity, short spore chains (in hooks or spirals) were produced. The spore surface was warty (Fig. 1).

Chromosomal DNA was extracted and purified as described previously (Hopwood et al., 1985). Cloning of $16 \mathrm{~S}$ rRNA genes after PCR-mediated amplification from genomic DNA was carried out as described previously (Lee et al., 2000). The cloned $16 \mathrm{~S}$ rRNA gene sequence was determined by using a model ALFexpress DNA sequencer (Pharmacia

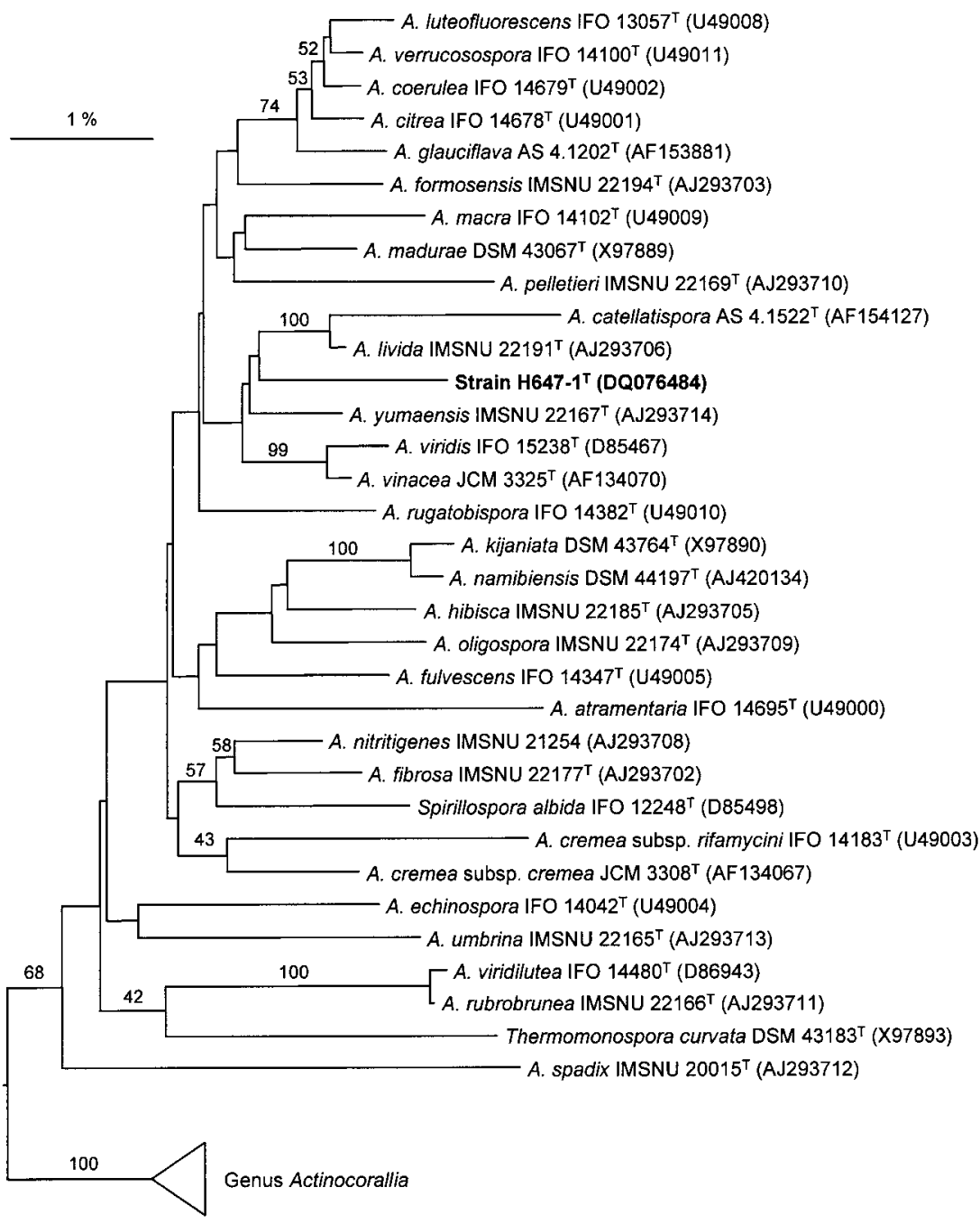

Fig. 2. Phylogenetic tree showing the position of strain $\mathrm{H} 647-1^{\top}$ within the radiation of the family Thermomonosporaceae. The tree was reconstructed by the neighbour-joining method from evolutionary distances calculated using the Jukes-Cantor coefficient. Streptosporangium roseum was used as an outgroup (data not shown). Bootstrap values at branching points are expressed as percentages from 1000 replications (only values greater than $40 \%$ are indicated). Bar, 1 nucleotide substitution per 100 nucleotides. 
Biotech) and the Cy5 AutoRead sequencing kit (Pharmacia). The almost-complete 16S rRNA gene sequence of strain H647- $1^{\mathrm{T}}$ determined in this study contained a continuous stretch of $1528 \mathrm{nt}$. The sequence obtained was aligned with those of the type strains of the family Thermomonosporaceae and related actinomycete taxa by using the program CLUSTAL X (Thompson et al., 1997). Evolutionary distance matrices were calculated by using the method of Jukes \& Cantor (1969), and a phylogenetic tree was reconstructed by the neighbour-joining method (Saitou \& Nei, 1987) based on the comparison of $1352 \mathrm{nt}$ present in all strains between positions 57 and 1480 positions (Escherichia coli numbering system). The reliability of the tree topology was evaluated by using the SEQBOOT, DNADIST, NEIGHBOR and CONSENSE programs in the PHYLIP package (Felsenstein, 1985, 1993), based on 1000 replications. The phylogenetic analysis (Fig. 2) indicated that isolate $\mathrm{H} 647-\mathrm{1}^{\mathrm{T}}$ formed a distinct cluster with members of the genus Actinomadura within the radiation encompassing members of the family Thermomonosporaceae, albeit with low bootstrap values. This relationship was also supported by the presence of all signature nucleotides specific for the family Thermomonosporaceae, except for Escherichia coli positions 603:635 (Zhang et al., 2001). In our study, most of the members of the family contained G-C pairs, instead of the A-U pairs previously described, for positions $603: 635$. The levels of $16 \mathrm{~S}$ rRNA gene sequence similarity between strain H647-1 ${ }^{\mathrm{T}}$ and members of the family Thermomonosporaceae ranged from $94 \cdot 3$ to $98 \cdot 2 \%$. The highest levels of $16 \mathrm{~S}$ rRNA gene sequence similarity were with A. livida $(98 \cdot 2 \%)$ and $A$. yumaensis $(97.9 \%)$, whereas the sequence similarity to another phylogenetic relative, Actinomadura catellatispora, was $96 \cdot 6 \%$. Strain $\mathrm{H} 647-1^{\mathrm{T}}$ could be readily distinguished from all members of the family Thermomonosporaceae by the possession of an additional extended helix (22 nt in length) between Escherichia coli positions 453 and 479. A similar-sized loop was also found in the sequences of the genera Actinomyces, Glycomyces, Jonesia, Mycobacterium, Nocardiopsis and Thermobifida (data not shown), although this stretch of the 16S rRNA gene sequence of strain H647$1^{\mathrm{T}}$ showed a unique nucleotide composition, suggesting that the sequence of this region might be useful for species identification.

The G+C content of the DNA of strain H647- $1^{\mathrm{T}}$ (determined by HPLC; Mesbah et al., 1989) was $67 \cdot 5 \mathrm{~mol} \%$.

The chemotaxonomic characteristics of strain $\mathrm{H} 647-1^{\mathrm{T}}$ were determined by using previously described methods (Kroppenstedt, 1985; Minnikin et al., 1977, 1980, 1984; Saddler et al., 1991; Staneck \& Roberts, 1974; Uchida \& Aida, 1984) for the analyses of the isomer of diaminopimelic acid, whole-cell sugars, isoprenoid quinones and phospholipids. The cell wall of isolate H647-1 ${ }^{\mathrm{T}}$ was of type III (mesodiaminopimelic acid was the diagnostic diamino acid) and the whole-cell sugars were of type B (madurose was the characteristic sugar) (Lechevalier \& Lechevalier, 1970). The acyl group of the muramic acid in the cell wall was of the acetyl type. The major menaquinones of isolate $\mathrm{H} 647-1^{\mathrm{T}}$ were MK-9 $\left(\mathrm{H}_{6}\right)(43 \%)$ and MK-9 $\left(\mathrm{H}_{8}\right)(40 \%)$. In addition, a small amount of MK-9 $\left(\mathrm{H}_{4}\right)$ was also detected. The polar lipid profile contained diphosphatidylglycerol, phosphatidylglycerol, phosphatidylinositol, phosphatidylinositol mannoside and unknown phospholipids. Nitrogenous phospholipids and phosphatidylcholine were not detected [the phospholipid pattern was type PI, described by Lechevalier et al. (1981)]. Mycolic acids were not detected. Cellular fatty acid methyl esters were prepared from cells grown on tryptic soy broth (Difco) at $30{ }^{\circ} \mathrm{C}$ for 3 days (Minnikin, 1988) and were analysed as described previously (Lee et al., 2000). The fatty acid profile of strain $\mathrm{H} 647-1^{\mathrm{T}}$ was characterized by the predominance of hexadecanoic acid $\left(\mathrm{C}_{16: 0}\right)$ and 10-methyloctadecanoic acid ( $\mathrm{C}_{18: 0}$ 10-methyl, tuberculostearic acid). Significant amounts of saturated, unsaturated and branched fatty acids were also present [fatty acid type 3a, according to the classification of Kroppenstedt \& Goodfellow (1991)]. The cellular fatty acid compositions of strain H647- $1^{\mathrm{T}}$ and closely related Actinomadura species are shown in Table 1.

The temperature and $\mathrm{pH}$ ranges for growth, and the degree of $\mathrm{NaCl}$ tolerance, were determined on ISP 2 medium. The decomposition of adenine, hypoxanthine, DL-tyrosine and xanthine was determined as described by Gordon et al.

Table 1. Fatty acid composition (\%) of strain $\mathrm{H} 647-1^{\top}$ and the type strains of closely related Actinomadura species

Examples of abbreviations for fatty acids: 16:0, hexadecanoic acid; 15:0 3-OH, 3-hydroxypentadecanoic acid; 18:0 10-methyl, 10methyloctadecanoic acid (tuberculostearic acid); $18: 1$ cis9, cis-9octadecenoic acid.

\begin{tabular}{|c|c|c|c|}
\hline Fatty acid & $\begin{array}{c}\text { Strain } \\
\text { H647-1 }^{\mathrm{T}}\end{array}$ & $\begin{array}{l}\text { A. livida } \\
\text { IMSNU } \\
22191^{\mathrm{T}}\end{array}$ & $\begin{array}{l}\text { A. yumaensis } \\
\text { IMSNU } \\
22167^{\mathrm{T}}\end{array}$ \\
\hline $12: 0$ & - & $0 \cdot 6$ & $1 \cdot 1$ \\
\hline $14: 0$ & $0 \cdot 5$ & $0 \cdot 5$ & $1 \cdot 3$ \\
\hline $15: 0$ iso & $1 \cdot 1$ & - & - \\
\hline $15: 0$ & - & $7 \cdot 4$ & $0 \cdot 6$ \\
\hline $16: 0$ iso & $15 \cdot 9$ & $9 \cdot 2$ & $5 \cdot 0$ \\
\hline $16: 1$ & $1 \cdot 4$ & - & - \\
\hline $16: 0$ & $27 \cdot 3$ & $20 \cdot 2$ & $38 \cdot 2$ \\
\hline $15: 03-\mathrm{OH}$ & - & - & $3 \cdot 8$ \\
\hline $16: 0 \quad 10$-methyl & - & - & $1 \cdot 8$ \\
\hline $17: 0$ anteiso & $0 \cdot 6$ & - & - \\
\hline $17: 1$ & - & $12 \cdot 4$ & $0 \cdot 7$ \\
\hline $17: 0$ & $0 \cdot 5$ & $8 \cdot 7$ & $0 \cdot 9$ \\
\hline $18: 1$ iso & $1 \cdot 6$ & - & - \\
\hline $17: 0 \quad 10$-methyl & - & $17 \cdot 0$ & $2 \cdot 0$ \\
\hline $18: 1$ cis 9 & $19 \cdot 1$ & $3 \cdot 8$ & $8 \cdot 6$ \\
\hline $18: 0$ & $4 \cdot 4$ & $6 \cdot 9$ & $3 \cdot 9$ \\
\hline $18: 0 \quad 10$-methyl & $25 \cdot 6$ & $11 \cdot 9$ & $29 \cdot 5$ \\
\hline $19: 1$ & - & $1 \cdot 0$ & $2 \cdot 7$ \\
\hline
\end{tabular}


Table 2. Phenotypic properties that differentiate strain $H 647-1^{\top}$ from the type strains of closely related Actinomadura species

+, Positive; -, negative; ND, not determined. Data were taken from the present study, Meyer (1989) and Lu et al. (2003).

\begin{tabular}{|c|c|c|c|c|}
\hline Characteristic & Strain H647-1 ${ }^{\mathrm{T}}$ & $\begin{array}{l}\text { A. catellatispora } \\
\text { IFO } 16341^{\mathrm{T}}\end{array}$ & $\begin{array}{c}\text { A. livida } \\
\text { IMSNU } 22191^{\mathrm{T}}\end{array}$ & 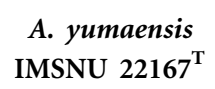 \\
\hline \multicolumn{5}{|l|}{ Morphology } \\
\hline Spore-chain arrangement & Hooks, spirals & Straight & Hooks, spirals & Hooks \\
\hline Spore-surface ornamentation & Warty & Smooth & Irregular & Smooth \\
\hline \multicolumn{5}{|l|}{ Growth on ISP 2 medium } \\
\hline Aerial mycelium & None & Yellow & None & None \\
\hline Substrate mycelium & Blackish purple & Light yellow & Brown & Yellowish brown \\
\hline Diffusible pigment & Dark brown & None & None & Orange \\
\hline \multicolumn{5}{|l|}{ Acid produced from: } \\
\hline L-Arabinose & + & ND & + & - \\
\hline Glycerol & + & ND & - & + \\
\hline D-Mannitol & + & ND & + & - \\
\hline L-Rhamnose & - & $\mathrm{ND}$ & + & - \\
\hline Salicin & + & ND & - & + \\
\hline D-Sorbitol & - & ND & + & - \\
\hline Sucrose & + & ND & - & + \\
\hline D-Xylose & + & ND & + & - \\
\hline \multicolumn{5}{|l|}{ Decomposition of: } \\
\hline Casein & + & - & $-{ }^{\star}$ & + \\
\hline DNA & + & ND & + & - \\
\hline Hypoxanthine & - & - & - & + \\
\hline Starch & + & - & $-^{\star}$ & + \\
\hline Tween 80 & - & $\mathrm{ND}$ & + & + \\
\hline Tyrosine & - & - & - & + \\
\hline Xanthine & - & - & - & + \\
\hline \multicolumn{5}{|l|}{ Growth conditions } \\
\hline $45^{\circ} \mathrm{C}$ & + & - & - & + \\
\hline $3 \% \mathrm{NaCl}$ & + & ND & - & + \\
\hline
\end{tabular}

${ }^{\star}$ Differs from data in a previous description (Meyer, 1989).

(1974). Urease activity was determined by means of a colour change using Bacto urea broth (Difco). The production of hydrogen sulfide was tested using a lead acetate strip. Catalase activity was determined with a $3 \%(\mathrm{v} / \mathrm{v})$ hydrogen peroxide solution. Nitrate reductase activity was determined with an equal mixture of $0.5 \% \alpha$-naphthylamine and $0.8 \%$ sulfanilic acid. The hydrolysis of casein, gelatin and starch was studied by using previously described methods (MacFaddin, 1981). The hydrolysis of DNA was determined using Bacto DNase test agar (Difco). Acid production from carbohydrates was determined by means of a colour change in Bacto OF basal medium (Difco) supplemented with each substrate at a final concentration of $1 \%(\mathrm{w} / \mathrm{v})$. All test strains produced acid from D-cellobiose, D-fructose, D-glucose, maltose and D-trehalose but not from D-galactose, Dlactose, D-mannose, D-melezitose, melibiose, methyl $\alpha$-Dglucoside, methyl $\alpha$-D-mannoside, D-raffinose, L-sorbose, adonitol, 2,3-butanediol, dulcitol, meso-erythritol, myoinositol, 1,2-propanediol and D-xylitol. Decomposition of aesculin and gelatin and growth in the presence of $2 \%$ $\mathrm{NaCl}$ were observed in all test strains. All test strains possessed nitrate reductase activity but not urease activity. A range of phenetic characteristics that distinguish strain H647- $1^{\mathrm{T}}$ from closely related species of the genus Actinomadura are listed in Table 2.

A broad range of phenetic and genetic data suggest that strain H647-1 ${ }^{\mathrm{T}}$ merits species status in the genus Actinomadura of the family Thermomonosporaceae. The name Actinomadura hallensis sp. nov. is proposed.

\section{Description of Actinomadura hallensis sp. nov.}

Actinomadura hallensis (hall.en'sis. N.L. fem. adj. hallensis of Mt. Halla, Jeju Island, Republic of Korea, the origin of the soil sample from which the type strain was isolated).

Gram-positive. Catalase-positive. Urease-negative. Nitrate is reduced to nitrite. $\mathrm{H}_{2} \mathrm{~S}$ is produced. Good growth on ISP 
2, ISP 3 and ISP 4 media. Forms a well-developed, nonfragmenting substrate mycelium that is blackish purple on ISP 2 medium, moderate brown on ISP 3 medium and greyish reddish purple on ISP 4 medium. A dark-browncoloured pigment is produced on ISP 2 medium. On ISP 3 and ISP 4 media, a moderate amount of white aerial mycelia is formed, which matures into short spore chains in hooks or spirals. The spore surface is warty. The temperature range for growth is $20-45^{\circ} \mathrm{C}$. The optimum $\mathrm{pH}$ for growth is $7 \cdot 0$. Acid is produced from L-arabinose, D-cellobiose, $\mathrm{D}$-fructose, D-glucose, glycerol, maltose, D-mannitol, salicin, sucrose, D-trehalose and D-xylose. Decomposes casein, DNA, aesculin, gelatin and starch. No acid is produced from adonitol, 2,3-butanediol, dulcitol, meso-erythritol, D-galactose, myoinositol, D-lactose, D-mannose, D-melezitose, melibiose, methyl $\alpha$-D-glucoside, methyl $\alpha$-D-mannoside, 1,2propanediol, D-raffinose, L-rhamnose, D-sorbitol, L-sorbose or D-xylitol. Does not decompose hypoxanthine, tyrosine, Tween 80 or xanthine. Grows in the presence of $3 \% \mathrm{NaCl}$. Type III/B cell wall (meso-diaminopimelic is the diagnostic diamino acid and madurose is the characteristic sugar). The acyl group of the muramic acid is of the acetyl type. The predominant menaquinones are MK-9 $\left(\mathrm{H}_{6}\right)$ and MK-9 $\left(\mathrm{H}_{8}\right)$, with a minor amount of MK-9 $\left(\mathrm{H}_{4}\right)$. Type PI phospholipid pattern (no diagnostic phospholipid). Mycolic acids are absent. The predominant fatty acids are hexadecanoic acid $\left(\mathrm{C}_{16: 0}\right)$ and tuberculostearic acid $\left(\mathrm{C}_{18: 0}, 10\right.$-methyl). Significant amounts of saturated, unsaturated and anteisobranched fatty acids are also present. The $\mathrm{G}+\mathrm{C}$ content of the DNA (determined by HPLC) is $67.5 \mathrm{~mol} \%$.

The type strain is H647- $1^{\mathrm{T}}\left(=\mathrm{IMSNU} 50760^{\mathrm{T}}=\mathrm{KCTC}\right.$ $9992^{\mathrm{T}}=\mathrm{KCCM} 42245^{\mathrm{T}}=$ NRRL B- $\left.24436^{\mathrm{T}}\right)$, isolated from a soil sample from Mt. Halla, Jeju Island, Republic of Korea.

\section{Acknowledgements}

This work was supported by a research grant to the Research Center for Molecular Microbiology, Seoul National University, from the Korea Science and Engineering Foundation (KOSEF). The authors are indebted to $\mathrm{H}$. L. Yang for preparing the manuscript.

\section{References}

Felsenstein, J. (1985). Confidence limits on phylogenies: an approach using the bootstrap. Evolution 39, 783-791.

Felsenstein, J. (1993). PHYLIP (phylogeny inference package, version 3.51c. Distributed by the author. Department of Genome Sciences, University of Washington, Seattle, USA.

Goodfellow, M. (1992). The family Streptosporangiaceae. In The Prokaryotes, 2nd edn, pp. 1116-1138. Edited by A. Balows, H. G. Trüper, M. Dworkin, W. Harder \& K. H. Schleifer. New York: Springer.

Gordon, R. E., Barnett, D. A., Handerhan, J. E. \& Pang, C. H.-N. (1974). Nocardia coeliaca, Nocardia autotrophica, and the nocardin strain. Int J Syst Bacteriol 24, 54-63.

Hopwood, D. A., Bibb, M. J., Chater, K. F. \& 7 other authors (1985). Genetic Manipulation of Streptomyces, a Laboratory Manual. Norwich: John Innes Foundation.
Jukes, T. H. \& Cantor, C. R. (1969). .Evolution of protein molecules. In Mammalian Protein Metabolism, pp. 21-132. Edited by H. N. Munro. New York: Academic Press.

Kroppenstedt, R. M. (1985). Fatty acid and menaquinone analysis of actinomycetes and related organisms. In Chemical Methods in Bacterial Systematics, pp. 173-199. Edited by M. Goodfellow \& D. E. Minnikin. London: Academic Press.

Kroppenstedt, R. M. \& Goodfellow, M. (1991). The family Thermomonosporaceae. In The Prokaryotes, 2nd edn, pp. 10851114. Edited by A. Balows, H. G. Trüper, M. Dworkin, W. Harder \& K. H. Schleifer. New York: Springer.

Kroppenstedt, R. M., Stackebrandt, E. \& Goodfellow, M. (1990). Taxonomic revision of the actinomycete genera Actinomadura and Microtetraspora. Syst Appl Microbiol 13, 148-160.

Lechevalier, M. P. \& Lechevalier, H. A. (1970). Composition of whole cell hydrolysates as a criterion in the classification of aerobic actinomycetes. In The Actinomycetales, pp. 311-316. Edited by H. Prauser. Jena: Gustav Fischer.

Lechevalier, M. P., Stern, A. E. \& Lechevalier, H. A. (1981). Phospholipids in the taxonomy of actinomycetes. Zentralbl Bakteriol Hyg Abt 1 Suppl 11, 111-116.

Lee, S. D., Kang, S.-O. \& Hah, Y. C. (2000). Catellatospora koreensis sp. nov., a novel actinomycete isolated from a gold-mine cave. Int J Syst Evol Microbiol 50, 1103-1111.

Lu, Z., Wang, L., Zhang, Y., Shi, Y., Liu, Z., Quintana, E. T. \& Goodfellow, M. (2003). Actinomadura catellatispora sp. nov. and Actinomadura glauciflava sp. nov., from a sewage ditch and soil in southern China. Int J Syst Evol Microbiol 53, 137-142.

MacFaddin, J. F. (1981). Biochemical Tests for Identification of Medical Bacteria, 2nd edn. Baltimore: Williams \& Wilkins.

Mesbah, M., Premachandran, U. \& Whitman, W. B. (1989). Precise measurement of the $\mathrm{G}+\mathrm{C}$ content of deoxyribonucleic acid by highperformance liquid chromatography. Int J Syst Bacteriol 39, 159-167.

Meyer, J. (1989). Genus Actinomadura. In Bergey's Manual of Systematic Bacteriology, vol. 4, pp. 2511-2526. Edited by S. T. Williams, M. E. Sharpe \& J. G. Holt. Baltimore: Williams \& Wilkins.

Minnikin, D. E. (1988). Isolation and purification of mycobacterial wall lipids. In Bacterial Cell Surface Techniques, pp. 125-135. Edited by I. C. Hancock \& I. R. Poxton. Chichester: Wiley.

Minnikin, D. E., Patel, P. V., Alshamaony, L. \& Goodfellow, M. (1977). Polar lipid composition in the classification of Nocardia and related bacteria. Int J Syst Bacteriol 27, 104-117.

Minnikin, D. E., Hutchinson, I. G., Caldicott, A. B. \& Goodfellow, M. (1980). Thin layer chromatography of methanolysates of mycolic acid-containing bacteria. J Chromatogr 188, 221-233.

Minnikin, D. E., O'Donnell, A. G., Goodfellow, M., Alderson, G., Athalye, M., Schaal, A. \& Parlett, J. H. (1984). An integrated procedure for the extraction of bacterial isoprenoid quinones and polar lipids. J Microbiol Methods 2, 233-241.

Saddler, G. S., Tavecchia, P., Lociuro, S., Zanol, M., Colombo, E. \& Selva, E. (1991). Analysis of madurose and other actinomycete whole cell sugars by gas chromatography. J Microbiol Methods 14, 185-191.

Saitou, N. \& Nei, M. (1987). The neighbor-joining method: a new method for reconstructing phylogenetic trees. Mol Biol Evol 4, 406-425.

Shirling, E. B. \& Gottlieb, D. (1966). Methods for characterization of Streptomyces species. Int J Syst Bacteriol 16, 313-340.

Staneck, J. L. \& Roberts, G. D. (1974). Simplified approach to identification of aerobic actinomycetes by thin-layer chromatography. Appl Microbiol 28, 226-231. 
Thompson, J. D., Gibson, T. J., Plewniak, F., Jeanmougin, F. \& Higgins, D. G. (1997). The CLUSTAL_X Windows interface: flexible strategies for multiple sequence alignment aided by quality analysis tools. Nucleic Acids Res 25, 4876-4882.

Uchida, K. \& Aida, K. (1984). An improved method for the glycolate test for simple identification of the acyl type of bacterial cell walls. J Gen Appl Microbiol 30, 131-134.
Zhang, Z., Wang, Y. \& Ruan, J. (1998). Reclassification of Thermomonospora and Microtetraspora. Int J Syst Bacteriol 48, 411-412.

Zhang, Z., Kudo, T., Nakajima, Y. \& Wang, Y. (2001). Clarification of the relationship between the members of the family Thermomonosporaceae on the basis of $16 \mathrm{~S}$ rDNA, 16S-23S rRNA internal transcribed spacer and 23S rDNA sequences and chemotaxonomic analyses. Int J Syst Evol Microbiol 51, 373-383. 